\title{
ゴム変性エポキシ樹脂の相分離構造と機械的性質 ${ }^{\dagger}$
}

$\begin{array}{lllll}\text { 村 } & \text { 惇* 松 下 裕 } \text { 臣** }^{* *} \text { 識 忠 継** 新 保 正 樹*** }\end{array}$

\author{
Phase Separated Structure and Mechanical Properties \\ of Rubber-Modified Epoxy Resins \\ by
}

\section{Atsushi Murakami*, Hiroomi Matsushita**, Tadatsugu Yoshiki** and Masaki SHimBo***}

The morphology of phase-separation and the mechanical properties of amine cured rubbermodified epoxy resins were investigated.

The results of the dynamic mechanical properties and the microscopic observations indicated that the epoxy-rich matrix phase was plasticized by the dissolved rubber and the rubber-rich domains were dispersed homogeneously in the epoxy-rich matrix.

The rubber-modification of epoxy resins enhanced the fracture toughness against crack initiation and caused the crack arrest. The size of the plastic-deformed region at the crack tip was correlated well with the fracture toughness against crack initiation according to Dugdal's equation.

From the fatigue crack propagation (FCP) tests at a low frequency it has been shown that the presence of rubber domains introduces the interfacial debonding between the domain and the matrix as the result of stress response, which promotes the FCP at the low stress intensity factor range. キー・ワード：ゴム変性エポキシ樹脂, 相分離形態, 破壊じん性, 疲労き裂伝ぱ, 界面はく離

\section{1 緒言}

熱可塑性樹脂のゴム変性による耐衝撃性へ(3) ついては古くから検討さ记, ゴム補強機構, 最適ゴム 粒子径が明らかになり, 優れた機械的性質をもつ HI PS, ABS 樹脂が開発されている.

最近，エポキシ樹脂においてもじん性执よび耐衝撃 性を高めるために末端にカルボキシル基をるつアクリ ロニトリルブタジェンゴム (CTBN) による変性が考

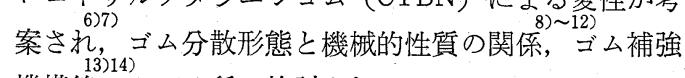
機構等について種々検討されている.

しかし，ゴム変性エポキシ樹脂を接着剤や複合材の 母材として工業的に応用するための, 材料特性に関す る知見は十分でない。

そこで本報ではビスフェノール型ェポキシ樹脂を低 分子量の液状 CTBN で変性し, 変性に伴う硬化物の 構造, 破壊じん性, 疲労き裂伝ぱ (FCP) 速度の変化 について検討を加兑，ゴム変性エポキシ樹脂の相分離 形態と破壞怙よび疲労挙動の関係を明らかにしようと した.

\section{2 実験}

試料には,ビスフェノール型エポキシ樹脂(Epikote
828）と, Table I に示す, 末端にカルボキシル基を もつアクリロニトリルブタジェンゴム (CTBN) との 混合物を硬化したものを用いた，陚料調製方法は，先 ずエポキシ樹脂100部 (重量)と CTBN 80 部 (重量) の混合物をテトラ-n-ブチルアンモニウムヨージドを 触媒として $150^{\circ} \mathrm{C} て ゙ 1$ 時間, 前反応させた。触媒の量 はゴム 100 部（重量）飞対して 1 部（重量）の触媒を 用いた，前反応させた混合物は透明になり， CTBN がエポキシ樹脂に完全に相容することを示した．前反

Table I. Chemical structure and properties of CTBN rubber.

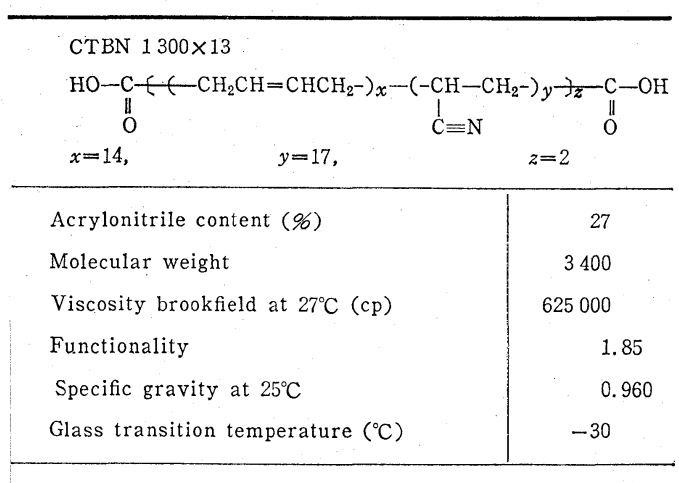

$\dagger$ 原稿受理 昭和60年 1月14日 Received Jan.14, 1985

* 正会員 姫路工業大学 姫路市書写, Himeji Institute of Technology, Shosha, Himeji

** 姫路工業大学 姫路市書写, Himeji Institute of Technology, Shosha, Himeji

*** 正会 員 関西大学工学部 吹田市千里山, Faculty of Engineering, Kansai University, Senriyama, Suita 
応させた混合物にエポキシ樹脂の所定量と, 全エポキ シ樹脂のエポキシ基と当量の $4 ， 4$ イ゙ジアミノジフェニ ールメタン (DDM) を加光, $80^{\circ} \mathrm{C} て ゙ 2$ 時間, $180^{\circ} \mathrm{C} て ゙$ 6 時間硬化したものを実験試料とした。各硬化物のゴ ム含量は $0,5,10,15,20,30,45$ 重量\%とした:

動力学的性質は強制振動型粘弾性測定装置を用い, 測定温度範囲 $-120 \sim 220^{\circ} \mathrm{C}$, 周波数 $10 \mathrm{~Hz}$ で測定した。 静曲げ試験は四点曲げ法で行った.

破壞じん性試験はFig. 1 (a)に示す.DCB 試験片を インストロン型引張試験機でクロスヘッド速度 0.5 $\mathrm{mm} / \mathrm{min}, 25^{\circ} \mathrm{C}$ の空気中で引張ることによって行った.

(a)

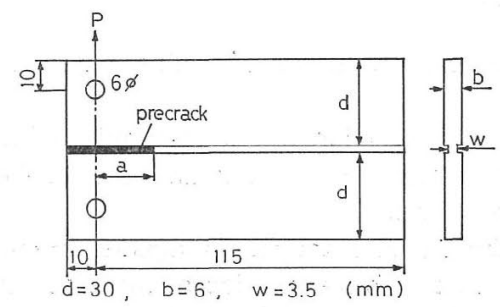

(b)

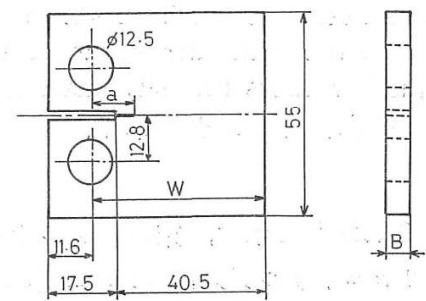

$\mathrm{B}=6.5, \quad W=46.4$

Fig. 1. Shape and dimension of test specimens; (a) double cantilever beam specimen for the fracture toughness test, (b) compact tensile specimen for the fatigue crack propagation test.

破壞じん性 $K_{c}$ 浪, $K_{15}=\left(\mathrm{Pa} / \mathrm{d}^{3 / 2} b^{1 / 2} w^{1 / 2}\right):(3.467+$

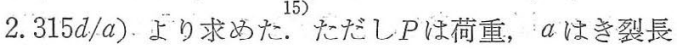
さ， dbwは試験片寸法で伺る、ひずみエネルギ解放率 （破壞エネルギ） $G_{c}$ は， $G_{c}=\left(K_{c}^{2} / E\right)\left(1-\nu^{2}\right)$ より求 めた。ただしEは弾性率，レはポアソン比である。

疲労き裂伝ぱ試験は Fig. 1 (b)に示す CT 試験片を 用い三角波の一定繰返し荷重のもとで, 繰返し速度 15 cycle $/ \mathrm{min}, 25^{\circ} \mathrm{C}$ 空気中で行った. 応力桩大係数変動 幅 $\Delta K=(\Delta P \sqrt{a} / B W) Y(a / W)$ 上り求め宎. ここに, $Y(a / W)=29.6-185.5(a / W)+655.7(a / W)^{2}-1017$ $(\alpha / W)^{3}+638.9(\alpha / W)^{4}$ である。たでし， $\Delta P$ は変動荷 重幅， $a$ はき裂長さ，Bは板厚，Wは試料幅で岉る。 荷重比 $\left(P_{\max } / P_{\min }\right)$ は裂伝ぱ速度に影響を与光る が, 本実験では $P_{\min }=0$ の条件で行った.

また，透過電子顕微鏡，走香電子顕微鏡によりゴム 分散形態を観察した。

3 結果古よび考察

\section{$3 \cdot 1$ 動力学的管質と相分離形態}

ゴム含量の異なる硬化エポキシ樹脂（それぞれ０， 15，30，45重量％）の動力的性質をFig.2 に示した。 室温近傍の動的弾性率はゴム含量の増大とともに減少 し, 各系の $\tan \delta$ 曲線には低温と高温に二つの転移ピ ークが出現している。高温側のピークはエポキシ樹脂 のガラス転移温度 $\left(E T_{g}\right)$ である。ゴム含量が $0 \%$ 系 の低温側のー $35^{\circ} \mathrm{C}$ に和けるピークは, 硬化剤に第 1 級

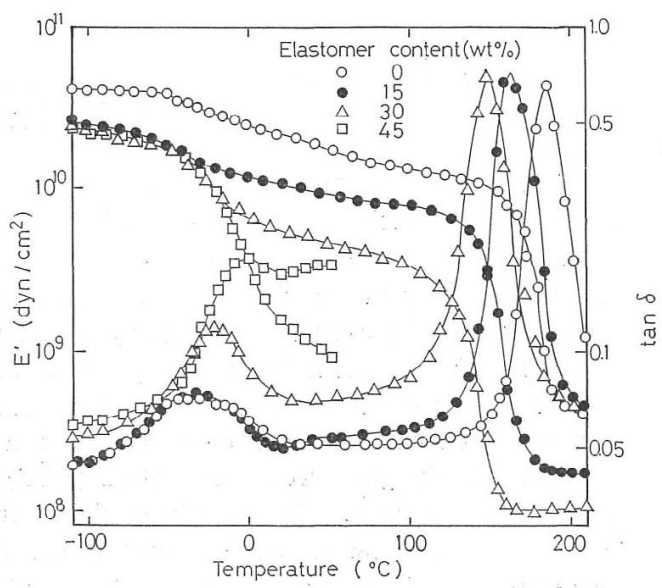

Fig. 2. Temperature dependence of dynamic modulus $E^{\prime}$ and $\tan \delta$ for CTBN-modified epoxy resins.

アミンを用いたときに生じるヒドロキシェーテル構造 に原因する $\beta$ 緩和である。低温側のピーク温度は, ゴ ム含量の增大ととるに高温側に移行しながらピーク高 さも增大している. ゴム含量が增大することによって 生じる低温側のピークは, 相分離したゴム相のガラス 転移温度 $\left(R T_{g}\right)$ 之関係していると思われる。

Fig. 3 は超薄切片を才スミウム染色したざム含量 30 \%系の透過電顕写真を示したものである。エポキシ樹 脂とゴムは相分離を起し，ゴムリッチな相を形成して

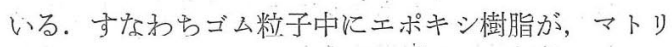
ックスのエポキシ相にゴムが含まれていることが明ら

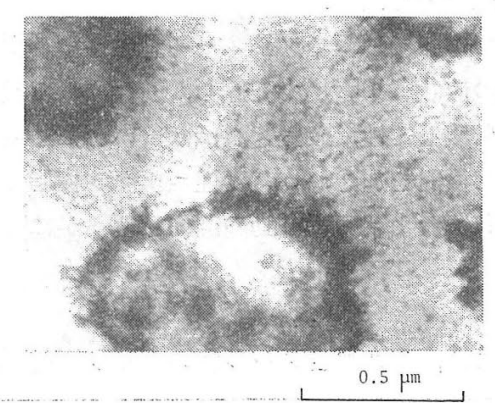

Fig. 3. Transmission electron micrograph of CTBN-modified epoxy resin(CTBN conc./ $30 \mathrm{wt} \%$ ). 
かである。 $R T_{g}$ がゴム含量の增大とともに高温側に 移行するのほ，ゴム粒子内にもエポキシ樹脂が相溶し ていること童付けるものである。

Fig. 4 はゴム含量と $E T_{g}$ の関係を示したものであ る. $E T_{g}$ はゴム含量とともに直線的に低下している。 $E T_{g}$ の低下はマトリックスのエポキシ相がゴムによっ て可塑化されるためであうら。さこの $E T_{q}$ とゴム含量 の関係を，式(1)に示す Gordon Taylor の理論より， マトリックスのエポキシに相溶したゴム量を求めた。

$$
\frac{1}{T_{g}}=\frac{1}{W_{1}+K W_{2}}\left(\frac{W_{1}}{T_{g 1}}+\frac{K W_{2}}{T_{g 2}}\right)
$$

ただし $T_{g}$ はエポキシーゴム相溶系のガラス転移温 度， $T_{g 1}$ は未変性エポキシ樹脂のガラス転移温度, $T_{g 2}$ はゴムのガラス転移温度で CTBN $\times 13$ ではー30 ${ }^{\circ} \mathrm{C} ， W_{1}$ は土ポキシの重量分率， $W_{2}$ はゴムの重量分

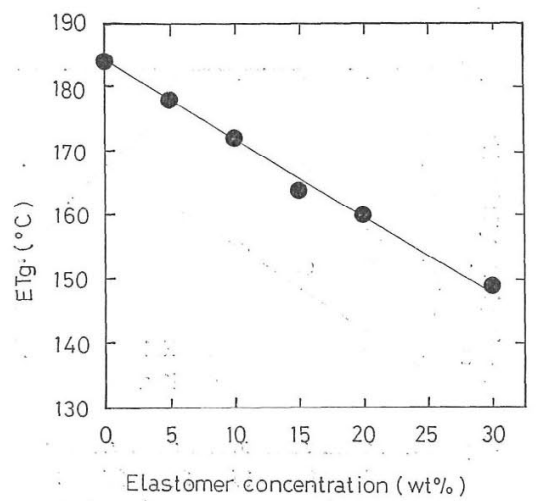

Fig. 4. Dependence of glass transition temperature $E T_{g}$ on elastomer concentration of CTBN-modified epoxy resins.

Table II. Weight fractions of dissolved rubber and phase-separated rubber determined from Gordon-Taylor equation.

\begin{tabular}{c|c|c}
\hline $\begin{array}{c}\text { Weight } \\
\text { fraction } \\
W_{R}(\%)\end{array}$ & $\begin{array}{c}\text { Weight fraction of } \\
\text { dissolved rubber } \\
W_{d}(\%)\end{array}$ & $\begin{array}{c}\text { Weight fraction of } \\
\text { phase-separated rubber } \\
W_{p}(\%)\end{array}$ \\
\hline 0 & - & - \\
5 & 1.16 & 3.84 \\
10 & 3.23 & 6.77 \\
15 & 5.29 & 9.71 \\
20 & 6.11 & 13.89 \\
30 & 8.27 & 21.73 \\
\hline
\end{tabular}

率，Kは 2 相間の固有定数でニポキンーCTBN 系では $K=0.88$ とした. Table II に各系のエポキシ樹脂マ トリックスに相溶したゴム重量を示した。

Fig. 5 は，ゴム変性エポキシ樹脂を液体窒素で冷や 乙，衝撃的に破壞させた破面の走査電子顕微鏡写真の 1 例である.この写真からもゴムが相分離しているこ とがわかる。この写真を用いて，Chalkley のPin

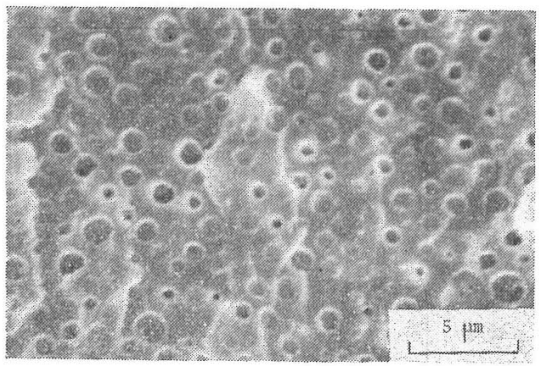

Fig. 5. Electronfractograph of CTBN-modified epoxy resin (CTBN conc./30 wt \%).

Table III. Volume fraction and average domain size determined from pin drop test.

\begin{tabular}{c|r|r|r|r}
\hline $\begin{array}{c}\text { Weight } \\
\text { fraction }\end{array}$ & $\begin{array}{r}\text { Volume } \\
\text { fraction }\end{array}$ & \multicolumn{2}{|c|}{$\begin{array}{c}\text { Volume fraction of } \\
\text { phase-separated rubber } \\
W_{R}(\%)\end{array}$} & $\begin{array}{l}\text { Average } \\
\text { domain } \\
\text { size }\end{array}$ \\
\hline 0 & - & - & - & - \\
5 & 4.30 & 4.17 & 3.34 & 0.46 \\
10 & 8.66 & 9.33 & 6.03 & 0.45 \\
15 & 13.10 & 22.67 & .8 .89 & 0.97 \\
20 & 17.59 & 26.83 & 12.91 & 1.03 \\
30 & 26.80 & 42.33 & 20.96 & 2.67 \\
\hline
\end{tabular}

$\phi_{p}$ determined from pin drop test.

$\phi^{\prime} p$ determined from Gordon-Talor equation.

drop test 法により相分離したゴムの体積分率 $\phi_{p}$ 末 よび平均ゴム粒子径至求め Table III に示した。 ゴム含量の增大とともに平均ゴム粒子径は大きくなっ ている. Table III には Gordon-Taylor の式より求 あた相分離ゴム体積分率 $\phi_{p}^{\prime}$ も示した。.高ゴム含量の 系ほど, 走查電子顕微鏡写真より求めた $\phi_{p}$ は, 実際 に混入したゴムの体積分率 $V_{R}$ よりも，大きくなって いる。このことから車相分離したゴム粒子にもさポキ シ樹脂が含まれていることとは明らかであり，ゴム含量 の増大とともに相分離したざム粒子に相溶するエポキ シ樹脂の割合も高くなることを示す。

Fig: 6 は，四点曲げ試験法によって求めた曲げ弾性 率との関係を示したもので西る。ゴム粒子を分散させ た高分子材料の弾性率と洞間には Kerner の式が成立 することが知られている。 エポキシ樹脂のポアソン比 を0.35とした場合，Kernerの式は式(2)のよらになる。

$$
\frac{E}{E_{1}}=\frac{1-\phi_{2}}{1+0.86\left(1+1.1 \phi_{2}\right) \phi_{2}}
$$

ただし，Eは相分離系の弾性率， $E_{1}$ はマトりック スの弾性率， $\phi_{2}$ はゴム粒子の体積分率である。，Gordon-Tayler の式上り求めた $\phi_{p}^{\prime}$.と, 未変性エポキシ 樹脂と変性エポキシ樹脂の曲外弾性比との関係を示し たものが Fig.7 である。実線は式(2)より求めた理論 值である。低ゴム含量のところでは， $\phi_{p}^{\prime}$ を用いた場 合曲げ弾性比は理論值に近づく。しかし高ゴム含量の 


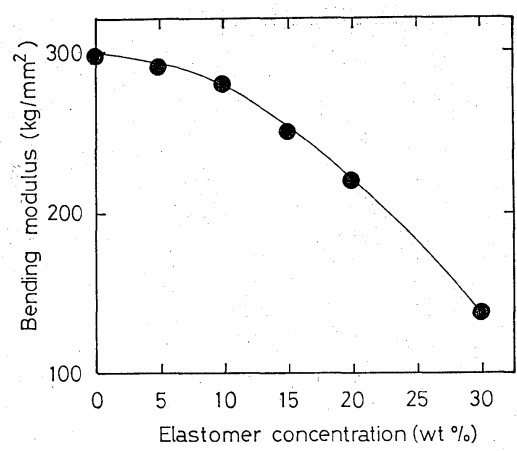

Fig. 6. Dependence of bending modulus on elastomer concentration of CTBN-modified epoxy resins.

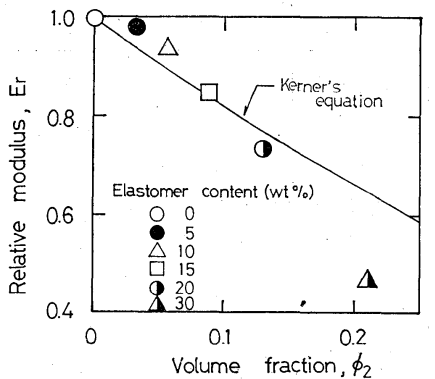

Fig. 7. Relationship between relative modulus and volume fraction of phase-separated rubber for CTBN-modified epoxy resins. Line represents generalized Kerner's equation.

ところでは Kerner 式からはずれてくる.これは， Table II に示したよらに，ゴム含量の高いものほぞ マトリックスのエポキシ相に相溶するゴム量が多くな り，マトリックスの弾性率が低下するためであろう。

一方，電子顕微鏡写真より求めた $\phi_{p}$ は Kerner 式 に全く適用できない，これは式(2)をマトリックスの弾 性率がゴム粒子の弾性率よりはるかに大きいことを仮 定して，導いていることに関係していると思われる. 先に述べたごとく，相分離したゴム粒子内にもエポキ シ樹脂がかなり包含され，ゴム粒子の弾性率がかなり 高くなっていると考えられる.

以上のことより，本実験で調製したゴム変性エポキ シ樹脂は，エポキシマトリックスにゴム粒子が分散し た形態をるち，マトリックスのエポキシ樹脂にゴムの 一部が相溶し, ゴム粒子にもエポキシ樹脂が相溶して いることがわかる。

\section{$3 \cdot 2$ ゴム変性エポキシ樹脂の破壊じん性}

ゴム变性したエポキシ樹脂の DCB 試験片を用いた 破壞じん性試験に抢いて，ゴム含量30\%系を除くすべ ての系は， stick-slip によるき裂の不安定伝ぱが生じ る.き裂の伝ぱが開始する破壊じん性 $K_{c i}$, およびき 裂の伝ぱが停止する破壊じん性 $K_{c a}$ と, この $K_{c i}$,
$K_{c a}$ に対応する破壊エネルギ(ひずみエネルギ解放率) $G_{c i}, G_{c a}$ のゴム含量による変化を示したのが Fig. 8, 9 である. $K_{c i}$ と開始エネルギ $G_{c i}$ はゴム含量の増大 とともに增大し、ゴム含量20\%系で最大值を示した. ゴム含量が $30 \%$ になると，き裂は安定な伝ぱを示し， ゴム変性による破壊じん性への効果は隇少する。また， $K_{c a}$ 拉よび停止ェネルギ $G_{c a}$ もゴム含量が高いもの ほど高い值を示した.ゴム含量の $20 \%$ 系では $G_{c i}, G_{c a}$ ともに未変性エポキシ樹脂の約 4 倍ほど高くなってい る. $K_{c a}, G_{c a}$ がゴム変性によって高められることは, 実用的意味でも重要なことである。なぜならば，何ら かの理由で万一き裂が伝ぱしても， $K_{c a} ， G_{c a}$ が高け れば破壊に至る前にき裂が停止するからである。ゴム 变性によって $K_{c a}, G_{c a}$ が高くなるのは塑性変形の緩 和時間が短くなり，急速に走るき裂を停止させるから であるう。

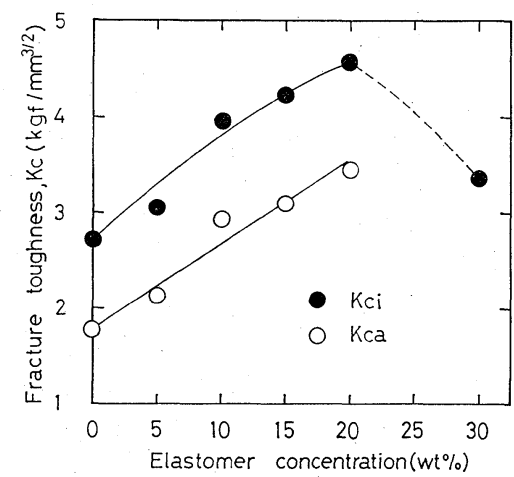

Fig. 8. Dependence of fracture toughness on elastomer concentration of CTBN-modified epoxy resins.

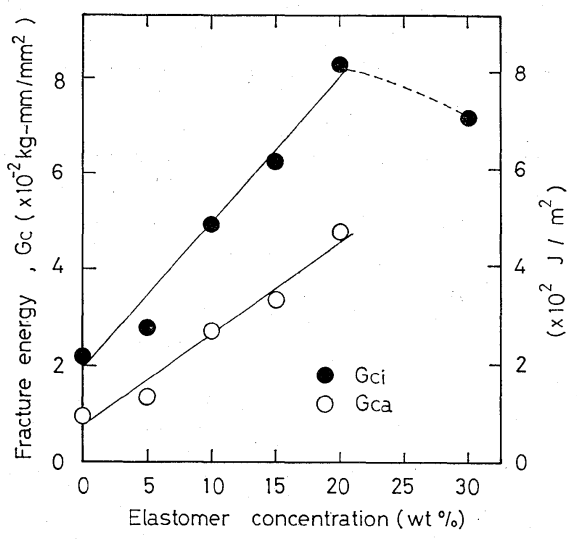

Fig. 9. Dependence of fracture energy on elastomer concentration of CTBN-modified epoxy resins.

stick-slip の不安定破壊機構を考察するために，走 査電子顕微鏡により破面を観察した。Fig.10は，き 裂の不安定伝ぱした破面の 1 例を示したものである. 


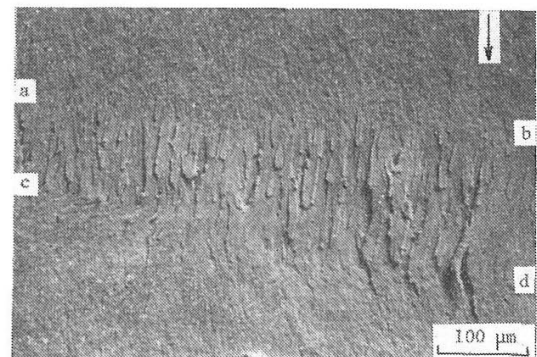

Fig. 10. Electronfractograph of CTBN-modified epoxy resin. An arrow shows the direction of crack propagation.

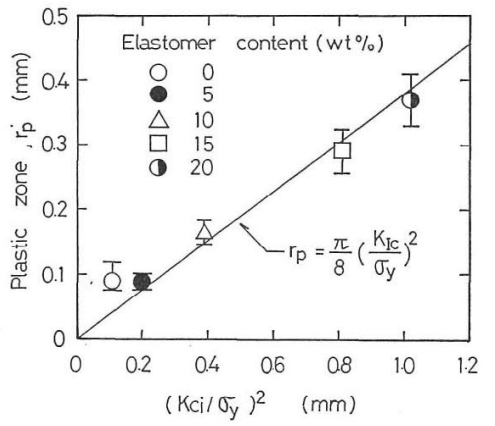

Fig. 11. Relationship between plastic zone $r_{p}$ and $\left(K_{c i} / \sigma_{y}\right)^{2}$ for CTBN-modified epoxy resins. Line represents Dugdal's equation.

き裂は $a b$ ラインで停止し，ab ラインから新たにき 裂の伝ぱが開始する。 ab-cd 間はき裂が不安定伝ぱす

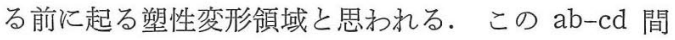
の寸法 $r_{b}$ と，き裂伝ぱが開始する破壞じん性 $K_{c i}$ と の関係を示したものが Fig.11 である。ただし横軸は $\left(K_{c i} / \sigma_{y}\right)^{2}$ とし， $\sigma_{y}$ は試料の降伏応力である. 図中の 実線は Dugdale の理論式である。 ab-cd 間の寸法 $r_{p}$ と Dugdale の式より求められるき裂先端部の塑性変 形の大きさはよく一致している。このことは, ゴム变 性エポキシ樹脂の stick-slip な不安定き裂伝ぱに和け る破壞じん性 $K_{c i}$ の增大は, き裂先端部の塑性変形領 域の增大に原因していることは明らかである。また， $K_{c i}, G_{c i}$ がゴム含量 $20 \%$ 付近で最大值を示し，ゴム含 量が30\%になるとき裂が安定伝ぱするのは，高ゴム含 量になると相分離したゴム相にエポキシ樹脂が多量に 含まれ (Table III 参照) ゴム粒子がリジッドになり， エネルギ吸収源と関係する塑性変形が生じにくくなる ためであるら。

エポキシ樹脂のゴム変性物け相分離を起し, この相 分離が破壊じん性 $K_{c i}, K_{c a}\left(G_{c i}, G_{c a}\right)$ 高めるもの 之考克られる。破罯じん性は相分離形態に依存するこ 之は明らかであり, 蕞適相分離形態について現在種々 検討中である.

\section{$3 \cdot 3$ ゴム変性エポキシ樹脂の $\mathrm{FCP}$ 挙動}

ゴム含量を異にするエポキシ樹脂の FCP 速度 $d a / d n$ 之応力桩大係数変動幅 $\Delta K$ の関係を Fig. 12 に示した. 未変性エポキシ樹脂と同様にゴム変性エポキシ樹脂も パリスの式 $d a / d n=C^{\prime} \Delta K^{m}$ の関係が成立する. 延性 村料になればmの值は 2 に近づくことが知られて和り， 本実験に特いてもゴム含量の高い系汪どmの值は低く なり，延性的な材料になると言光る、 $\Delta K$ 值の高いと ころでは，ゴム含量の高い系汪ど $\mathrm{FCP}$ 速度が遅くな って打り, 疲労によるき裂の安定伝ぱから不安定伝ぱ （破壞）飞変化する応力拡大係数 $K_{c f}$ は，破壞じん性 $K_{c}$ とよく相関している。 しかし，ゴム変性系は未変 性エポキシ樹脂に比べ，かなり低い $\Delta K$ 值でさ裂が伝 ぱしている.ゴム変性エポキシ樹脂では $\Delta K$ 值の高い ところでき裂伝ぱ速度が著しく低下し，かつ不安定破 壞する $K_{e f}$ も高くなり，ゴム変性の効果が認められ るが，低い $\Delta K$ 值でき裂が伝ぱし材料特性として重要 な $\Delta K_{\mathrm{th}}$ が低下するものと思われる。すなわち，エポ キシ樹脂のゴム変性は，FCP 抵抗を高める有効な手 段であるとは必ずしも言光ない。

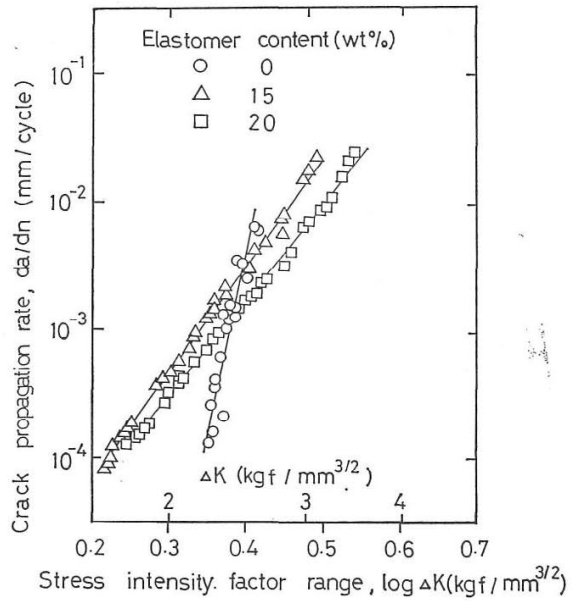

Fig. 12. Relationships between crack propagation rate and stress intensity factor range for CTBNmodified epoxy resins.

ゴム変性エポキシ樹脂の FCP 過程では，かなり低 い $\Delta K$ 值に和いてもき裂先端部でマトリックスーゴム 粒子界面のはく離 (debonding) のため多数のき裂の 核が生じ，この多数の当裂の核が合体しながらき裂は 伝ぱしていくるのと考光る。き裂はゴム粒子内む通過 するため， $\Delta K$ 值の高いところで伝ぱ速度が低下し， 破壞じん性值 $K_{c i}$ に対応する高い $K_{c f}$ で急速に不安 定伝ぱし，破壊に至るものと考光られる。

\section{4 結論}

末端はカルボキシル基をるつ液状アクリロニトリル ブタジェンゴム (CTBN) で変性したエポキシ樹脂の 相分離形態, 疲労強度, 破壞じえ性と破壞機構, 疲労 
き裂伝ぱ機構について検討し次の様な結論を得た...

…(1) ゴム変性エポキシ樹脂は相分離を起し，エポ゚キ シマトリックスにゴム粒子が分散した形態を示した。 ゴム変性物の $T_{g}$ はゴム含量の増大とともに直線的な 低下を示し，エポキシ相にゴムが相溶していることを 裏付けた。走查電子顕微鏡写真の Pindrop test 飞よ り求めたゴム粒子の体積分率 $\phi_{p}$ は, 混入したゴム体 積分率より向かなり大きくなり，ゴム粒子内にも五ポ キジ樹脂が包含さ准ているごとを示唆しだ.

(2) き裂の伝ぱが開始する破壊じん性 $K_{c i}$ ，開始工 京ルギ $G_{c i}$, 执よびき裂の伝ぱが停止する破壊じん性 值 $K_{c a}$ ，停止エネルギ $G_{c a}$ 快，ゴ公変性によらで高 められた. $K_{c i}$ と塑性変形領域の大きさとの関係は Dugdale の理論とよく一致し, こム变性によって、 $K_{c i}$ が高められるのは, き裂先端部の塑性変形領域の增大 に原因することが明らかになった。

（3）ぎム変性によって，高い $\Delta K$ 值で FCP 速度を 低下させたり，裂が不安定伝ぱする 応力拡大係数 $K_{c f}$ を增大させるが，未変性土ポキシ樹脂よりも低い $\Delta K$ 值でき裂の伝ぱが起り，エポキシ樹脂のゴム変性 はFCP 抵抗を高める有効な手段であるとは必ずしも 言光ない。

(昭和59年 5 月28日 日本材料学会第33期学術講演会にて講演)

\section{参 考 文 献}

1) E. H. Marrz, G. V. Claver and M. Bear, J. Polym. Sci., 22, 325 (1956).

2) L. E. Nielsen, Mechanical Properties of Polymers, Reinhold (1962) New York.

3) R.P. Kambour, Polymer, 5, 143 (1964).

4) M. Matsuo, Polym. End, Sci., 9, 3, 206 (1969).

5) 河合 弘, 高分子, 28，518 (1979).

6) E.H. Rowe, A.R. Siebert and S. S. Drake, Mod. Plast,, $\mathbf{4 7}, 110$ (1970).

7) J. N. Sultan and F. J. McGarry; Polym. Eng. Sci.,
13. 29 (1973).

8) W. D. Bascom, R. L. Cottington, R. L. Jones and P. Payser, J. Appl. Polym. Sci., 19, 2545 (1975).

9) N. C. Paul, D. H. Richards and D. Thompson, Polymer, 18, 945 (1977).

10) D.M. Brewis, J. Comyn and J.R. Fowler, Polymer, 18, 951 (1977).

11) L. T. Manzione and J.K. Gilham, J. Appl. Polym. Sci., 26, 907 (1981).

12) W. D. Bascom, R. Y. Ting, R. J. Moulton, C. K. Riew and A. R. Siebert, J. Mater. Sci., 16, 2657 (1981).

13) S. K. Douglass, P. W.R. Beaumont and M.F. Ashby, J. Mater. Sci., 15, 1109 (1980):

14) S. C. Kunz and P.W. R. Beaumont, J. Mater. Sci., 16. 3141 (1981).

15) S. M. Wiederhorn and R. L. Moses, J. Appl. Phys., 39, 1569 (1968).

16）岡村引之, “線形破滾力学入門”, p.218 (1976) 培風館.

17) S. A. Sutton, Eng. Fract. Mech., 6, 587 (1974).

18）越智光一; 新保正樹, 日本化学会誌， 1975(9), 1600.

19) L. T. Manzione and J.K. Gillham, J. Mater. Sci., 16, 889 (1981).

20) T. G. Fox and S. Loshaek, J. Polym. Sci., 15, 371 (1955).

21) H. W. Chalkley, J. Cornfield and H. Park, Science, 110, 295 (1949).

-22) 渡辺治夫, 粉体工学研究会誌, 8, 195 (1971).

23) J. C. Halpin, J. Copos. Mater., 3, 732 (1969).

24) D. S. Dugdale, Mech. Phys. Polids, 8, 100 (1960).

25) Yamini and R.T. Young, J. Mater. Sci., 15, 1823 (1980).

26) A. J. Kinioch and J. G. Williams, J. Mater. Sci., 15, $987,(1980)$.

27）日本材料学会編，“材料学の最近の進歩”, p. 32 (1982) 白本材料学会. 